\title{
Eucalyptus growth and phosphorus nutritional efficiency as affected by soil compaction and phosphorus fertilization
}

\author{
Sérgio Ricardo Silva (D) ${ }^{a}$, Nairam Félix de Barros ${ }^{b}$, Roberto Ferreira de Novais ${ }^{c}$, \\ and Nicholas Brian Comerford ${ }^{d}$

\begin{abstract}
aNational Wheat Research Center (Embrapa Trigo), Brazilian Agricultural Research Corporation, Passo Fundo, Rio Grande do Sul, Brazil; 'Department of Soil Science, Federal University of Viçosa, Viçosa, Brazil; 'Department of

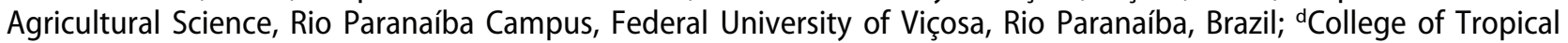 \\ Agriculture and Human Resources, University of Hawaii, Honolulu, USA
}

\begin{abstract}
Soil compaction interferes in soil nutrient transport and root growth. The aim of this work was to evaluate eucalypt growth and phosphorus (P) nutritional efficiency as affected by soil compaction and $P$ rates. The treatments were composed of a $3 \times 4$ factorial scheme (soil bulk densities levels versus $\mathrm{P}$ fertilization rates) for two weathered tropical soils, a clayey Ferralsol $\left(F_{\text {Clayey }}\right)$ and a sandy Ferralsol $\left(F_{\text {Sandy }}\right)$. The soil bulk densities assessed were $0.90,1.10$ and $1.30 \mathrm{~g} \mathrm{~cm}^{-3}$ for $F_{\text {Clayey, }}$ and $1.35,1.55$ and $1.75 \mathrm{~g} \mathrm{~cm}^{-3}$ for $F_{\text {Sandy }}$. The $P$ rates were $0,150,300$ and $600 \mathrm{mg} \mathrm{kg}^{-1}$ for $F_{\text {Clayey, }}$ and 0,100 , 200 and $400 \mathrm{mg} \mathrm{kg}^{-1}$ for $\mathrm{F}_{\text {Sandy }}$. Soil compaction reduced root growth, $\mathrm{P}$ content in the plant, $\mathrm{P}$ utilization efficiency and $\mathrm{P}$ recovery efficiency; and increased average root diameter. Phosphorus fertilization increased root length density, root surface area, dry matter, $\mathrm{P}$ content in the plant, $\mathrm{P}$ utilization efficiency and $P$ uptake efficiency; and decreased $P$ recovery efficiency. It was concluded that $P$ fertilization is not effective to offset the deleterious effects of soil compaction on eucalypt growth and nutrition.
\end{abstract}

\begin{abstract}
Abbreviations: $\mathrm{F}_{\text {Clayey }}$ : clayey Ferralsol; $\mathrm{F}_{\text {Sandy }}$ : sandy Ferralsol; $\mathrm{R}_{\text {Dens: }}$ root length density; $R_{\text {Diam }}$ : root diameter; $R_{\text {Surf: root surface area; }} R_{D M}$ : root dry matter; $\mathrm{S}_{\mathrm{DM}}$ : shoot dry matter; $\mathrm{WP}_{\mathrm{DM}}$ : whole-plant dry matter; $\mathrm{R}_{\mathrm{P}}$ : root $\mathrm{P}$ content; $S_{P}$ : shoot $P$ content; $W_{P}$ : whole-plant $P$ content; $P U_{t} E$ : $P$ utilization efficiency; $\mathrm{PU}_{\mathrm{p}} \mathrm{E}$ : $\mathrm{P}$ uptake efficiency; PRE: $\mathrm{P}$ recovery efficiency.
\end{abstract}

\section{ARTICLE HISTORY}

Received 23 October 2017

Accepted 10 October 2018

\section{KEYWORDS}

Eucalyptus camaldulensis; phosphorus nutrition; phosphorus utilization efficiency; root growth; soil bulk density

\section{Introduction}

Soil is exposed to severe stresses when subjected to mechanical pressures from the traction and slippage of machine tires during silvicultural activities (weed control, soil tillage and fertilization), harvesting, and timber transportation, which are performed several times in the same area. As a result, the use of heavy machinery can lead to soil compaction.

Soil compaction can reduce plant development by its negative effects on root growth, and the uptake of water and nutrients (Bengough et al. 2011; Głąb and Gondek 2014; Nosalewicz and Lipiec 2014; Silva, Barros, and Vilas Boas 2006). The uptake of nutrients is reduced when roots cannot access higher soil volume, due to the negative effects of compaction on soil physical properties related to the transport of water and nutrients through the soil. Above a given level, soil compaction reduces the diffusion of nutrients such as phosphorus (P) (Arvidsson 1999). Soil compaction also induces the change of some physiological and morphological features in the roots, which become

CONTACT Sérgio Ricardo Silva sergio.ricardo@embrapa.br N National Wheat Research Center (Embrapa Trigo), Brazilian Agricultural Research Corporation, PO Box 3081, Passo Fundo, Rio Grande do Sul 99050-970, Brazil

Color versions of one or more of the figures in the article can be found online at www.tandfonline.com/lcss. 
short, thick and scaly (Alameda and Villar 2012; Bejarano et al. 2010; Misra and Gibbons 1996; Silva et al. 2002), modifying nutrient uptake efficiency (Kristoffersen and Riley 2005; Nadian et al. 1996; Rosolem, Almeida, and Sacramento 1994). Therefore, agricultural and forest productivity may be temporarily or permanently impaired in compacted soils.

Although soil compaction represents a problem for the growth of managed forests, only a few experiments have evaluated the interactive effects of compaction levels on the nutrition of eucalypt and other forest species. In this context, the understanding of the interaction between soil compaction and the plant for $\mathrm{P}$ has practical relevance, since this nutrient is often the major limiting factor for eucalypt growth in highly weathered soils (Barros and Novais 1996).

The objectives of this work were to evaluate the eucalypt growth and $\mathrm{P}$ nutrition in response to compaction levels in two tropical Ferralsols, and to verify if the increase of $\mathrm{P}$ fertilization rate can offset the reduction of root growth caused by soil compaction.

\section{Materials and methods}

\section{Soils and greenhouse conditions}

Two typical highly weathered tropical soils from the Brazilian savanna region (Cerrado), with different textures, were collected in Sete Lagoas and Três Marias counties, in the state of Minas Gerais, Brazil: a clayey red rhodic Ferralsol ( $\mathrm{F}_{\text {Clayey }}$ ) and a sandy red-yellow rhodic Ferralsol ( $\mathrm{F}_{\text {Sandy }}$ ) (FAO 2014 (Latossolo Vermelho distroférrico argiloso and Latossolo Vermelho Amarelo distroférrico arenoso, respectively, in the Brazilian Soil Classification System)). Soil samples were collected from the upper $20 \mathrm{~cm}$ of the soil profile, passed through a $2-\mathrm{mm}$ sieve, air-dried, homogenized, and stored in the laboratory until use. Soil subsamples were collected for chemical and physical characterization (Table 1).

The experiment was carried out in a greenhouse for 100 days. The main weather conditions inside the greenhouse during the experimental period were as follows (mean \pm standard deviation): mean daily temperature of $17.8 \pm 2.4^{\circ} \mathrm{C}$, average relative humidity of $75.6 \pm 8.9 \%$, and average daily global solar radiation of $14.4 \pm 4.8 \mathrm{MJ} \mathrm{m}^{-2}$.

\section{Experimental design and treatments}

The treatments, individually for each soil, were composed of a $3 \times 4$ factorial scheme (soil bulk densities levels versus $\mathrm{P}$ fertilization rates), arranged in a completely randomized design, with four

Table 1. Chemical and physical properties of two tropical Ferralsols ( $F_{\text {Clayey }}$ and $\left.F_{\text {Sandy }}\right)$.

\begin{tabular}{|c|c|c|}
\hline Properties & F Clayey & $\mathrm{F}_{\text {Sandy }}$ \\
\hline $\mathrm{C}\left(\mathrm{g} \mathrm{kg}^{-1}\right)^{(1)}$ & 34 & 6 \\
\hline P-rem (mg L ${ }^{-1}$ ) (2) & 9.3 & 46.9 \\
\hline MPAC (mg kg $\left.{ }^{-1}\right)^{(3)}$ & 1050 & 300 \\
\hline$P\left(\mathrm{mg} \mathrm{kg}^{-1}\right)^{(4)}$ & 1.8 & 1.6 \\
\hline $\mathrm{K}\left(\mathrm{mg} \mathrm{kg}^{-1}\right){ }^{(4)}$ & 37.3 & 47.3 \\
\hline $\mathrm{Ca}^{2+}\left(\mathrm{cmol}_{\mathrm{c}} \mathrm{kg}^{-1}\right)^{(5)}$ & 1.1 & 0.0 \\
\hline $\mathrm{Mg}^{2+}\left(\mathrm{cmol}_{\mathrm{c}} \mathrm{kg}^{-1}\right)^{(5)}$ & 0.1 & 0.0 \\
\hline $\mathrm{Al}^{3+}\left(\mathrm{cmol}_{\mathrm{c}} \mathrm{kg}^{-1}\right)^{\prime(5)}$ & 1.1 & 0.5 \\
\hline $\mathrm{H}+\mathrm{Al}\left(\mathrm{cmol}_{\mathrm{c}} \mathrm{kg}^{-1}\right)^{(5)}$ & 8.7 & 3.0 \\
\hline $\mathrm{pH}^{(6)}$ & 4.6 & 4.9 \\
\hline$D_{S}\left(g_{c m}^{-3}\right)$ & 0.90 & 1.35 \\
\hline Clay $\left(\mathrm{g} \mathrm{kg}^{-1}\right)$ & 740 & 130 \\
\hline Silt $\left(\mathrm{g} \mathrm{kg}^{-1}\right)$ & 120 & 30 \\
\hline Sand $\left(\mathrm{g} \mathrm{kg}^{-1}\right)$ & 140 & 840 \\
\hline Texture & Clayey & Sandy \\
\hline
\end{tabular}


replicates. The soil bulk densities (considered by the authors as synonymous with soil compaction levels, from now on), within the same texture, were $0.90\left(\mathrm{D}_{0.90}\right.$, control, uncompressed $), 1.10\left(\mathrm{D}_{1.10}\right)$ and $1.30 \mathrm{~g} \mathrm{~cm}^{-3}\left(\mathrm{D}_{1.30}\right)$ for $\mathrm{F}_{\text {Clayey }}$; and 1.35 ( $\mathrm{D}_{1.35}$, control, uncompressed), $1.55\left(\mathrm{D}_{1.55}\right)$ and $1.75 \mathrm{~g}$ $\mathrm{cm}^{-3}\left(\mathrm{D}_{1.75}\right)$ for $\mathrm{F}_{\text {Sandy. The } \mathrm{P} \text { rates were } 0,150,300 \text { and } 600 \mathrm{mg} \mathrm{kg}} \mathrm{m}^{-1}\left(\mathrm{P}_{0}, \mathrm{P}_{150}, \mathrm{P}_{300}, \mathrm{P}_{600}\right.$, respectively) for $\mathrm{F}_{\text {Clayey; }}$ and $0,100,200$ and $400 \mathrm{mg} \mathrm{kg}^{-1}\left(\mathrm{P}_{0}, \mathrm{P}_{100}, \mathrm{P}_{200}, \mathrm{P}_{400}\right.$, respectively) for $\mathrm{F}_{\text {Sandy. }}$ The $\mathrm{P}$ rates chosen were based on previous studies (unpublished data) with other similar weathered savanna Brazilian soils, aiming to obtain the "maximum dry matter of the whole plant", which is information necessary to calculate the critical $\mathrm{P}$ fertilization rate (as will be described below).

The experimental unit consisted of a cylindrical polyvinyl chloride (PVC) pipe of $2400 \mathrm{~cm}^{3}$ (14.5 cm length, $14.5 \mathrm{~cm}$ internal diameter, with a wall thickness of $3 \mathrm{~mm}$ ), containing $2000 \mathrm{~cm}^{3}$ of soil after the process of compaction. The soils were fertilized before compaction, with the following nutrients $\left(\mathrm{mg} \mathrm{kg}^{-1}\right): 100 \mathrm{~N}, 150 \mathrm{~K}, 30 \mathrm{~S}, 48 \mathrm{Mg}, 0.82 \mathrm{~B}$ and $4 \mathrm{Zn}$, applied as $\left(\mathrm{NH}_{4}\right)_{2} \cdot \mathrm{SO}_{4}, \mathrm{KNO}_{3}, \mathrm{KCl}$, $\left(\mathrm{MgCO}_{3}\right)_{4} \cdot \mathrm{Mg}(\mathrm{OH})_{2} \cdot 5 \mathrm{H}_{2} \mathrm{O}, \mathrm{H}_{3} \mathrm{BO}_{3}$, and $\mathrm{ZnSO}_{4} \cdot 7 \mathrm{H}_{2} \mathrm{O} ; \mathrm{Ca}\left(\mathrm{H}_{2} \mathrm{PO}_{4}\right)_{2} \cdot \mathrm{H}_{2} \mathrm{O}$ was used as the source of $\mathrm{P}$. A solution of $\mathrm{CaCl}_{2} \cdot 2 \mathrm{H}_{2} \mathrm{O}$ was used to balance the $\mathrm{Ca}$ concentration in the soil samples, based on the highest rate of $\mathrm{P}$ applied. Since the soils were fertilized before compaction and the experimental units contained the same volume of soil $\left(2000 \mathrm{~cm}^{3}\right)$, the amount of nutrients in the compacted soils was higher than that in the uncompacted ones, this is, it was directly proportional to the soil bulk density treatments $\left(0.90,1.10\right.$ and $1.30 \mathrm{~g} \mathrm{~cm}^{-3}$ for $\mathrm{F}_{\text {Clayey; }}$ and $1.35,1.55$ and $1.75 \mathrm{~g} \mathrm{~cm}^{-3}$ for $\left.\mathrm{F}_{\text {Sandy }}\right)$.

After fertilization, the soil moisture was raised to the field capacity, and the soils were mixed and left to incubate for 10 days within sealed plastic bags.

\section{Packing of soils to predetermined bulk densities}

Immediately after the incubation period, the soils were mixed again before use in the compaction process. Four replicate cores of each soil bulk density level were created by packing predetermined weights of the soils into cylindrical PVC pipes using a hydraulic press and custom-made piston, similar to the method described by Skinner et al. (2009). A gap of $2.5 \mathrm{~cm}$ was left at the top of each core, giving a final soil depth and volume of $12 \mathrm{~cm}$ and $2000 \mathrm{~cm}^{3}$, respectively. To obtain relative uniformity of surface compaction, soils were compressed from the top in one event as one layer. After soil compression, the bottom of each pot was sealed with a 15-mm thick Styrofoam sheet. Seven 4-mm diameter holes were drilled in the bottom of each pot (through the Styrofoam sheet) to allow water drainage.

The soil bulk densities imposed by the compaction process remained unchanged during the experimental period, as it was observed in situ.

\section{Plant growth and $\mathbf{P}$ nutrition efficiency indexes}

Approximately twenty seeds of Eucalyptus camaldulensis were sown in each pot. Between eight and 15 days after emergence (DAE), thinning was performed, and only two seedlings remained in each pot until harvesting time. The assay was carried out for $100 \mathrm{DAE}$, maintaining the soil moisture near to field capacity by daily watering with distilled water. After that period, the plant shoot was cut and dried at $65{ }^{\circ} \mathrm{C}$ until a constant weight was achieved. A soil sample of $136 \mathrm{~cm}^{3}$ was withdrawn from each experimental unit, throughout the soil depth, with a $3.8-\mathrm{cm}$ internal diameter cylindrical sampler. Then, this soil sample was washed on a $0.25-\mathrm{mm}$ sieve to separate the roots, which were measured for root length $(\mathrm{L}, \mathrm{cm})$ using the line intersect method (Tennant 1975), and for average root diameter $\left(\mathrm{R}_{\text {Diam }}, \mathrm{cm}\right)$ with an optical micrometer attached to an ocular microscope $(\mathrm{n}=15$ measurements). Root length density $\left(\mathrm{R}_{\text {Dens }}, \mathrm{cm} \mathrm{cm}^{-3}\right)$ and root surface area $\left(\mathrm{R}_{\text {Surf }}, \mathrm{cm}^{2} \mathrm{~cm}^{-3}\right)$ were estimated using the following equations: $R_{\text {Dens }}=L / 136$, and $R_{\text {Surf }}=\left(\pi^{\star} R_{\text {Diam }}{ }^{\star} L\right) / 136$, where 136 is the soil volume $\left(\mathrm{cm}^{3}\right)$ sampled for root measurements. After these evaluations, the roots were dried at $65{ }^{\circ} \mathrm{C}$ until a constant weight was achieved. The remaining roots were removed from the pots, 
rinsed with water on a 0.50 - $\mathrm{mm}$ sieve until the complete elimination of soil particles, and then dried as described above. The dried samples of eucalypt tissues were weighed to obtain the following plant variables: root dry matter $\left(\mathrm{R}_{\mathrm{DM}}\right)$, shoot dry matter $\left(\mathrm{S}_{\mathrm{DM}}\right)$ and whole-plant dry matter $\left(\mathrm{WP}_{\mathrm{DM}}\right)$.

Samples of ground plant tissues were subjected to nitric and perchloric acid digestion (Johnson and Ulrich 1959), followed by the determination of $\mathrm{P}$ concentration using colorimetry. After that, the content of $\mathrm{P}$ in roots $\left(\mathrm{R}_{\mathrm{P}}\right)$, shoots $\left(\mathrm{S}_{\mathrm{P}}\right)$ and whole plant $\left(\mathrm{WP}_{\mathrm{P}}\right)$ was calculated, alongside the following nutrition efficiency indexes: i) $\mathrm{P}$ utilization efficiency (Siddiqi and Glass 1981): $\mathrm{PU}_{\mathrm{t}} \mathrm{E}$ $\left(\mathrm{g}^{2} \mathrm{mg}^{-1}\right)=\mathrm{WP}_{\mathrm{DM}}{ }^{2} / \mathrm{WP}_{\mathrm{P}}$; ii) $\mathrm{P}$ uptake efficiency (adapted from Swiader, Chyan, and Freiji 1994): $\mathrm{PU}_{\mathrm{p}} \mathrm{E}\left(\mu \mathrm{g} \mathrm{cm}^{-2}\right)=\mathrm{WP}_{\mathrm{P}} /$ total $\mathrm{R}_{\text {Surf }}$ by pot; iii) $\mathrm{P}$ recovery efficiency (adapted from Greenwood et al. 1989): $\mathrm{PRE}(\%)=\left(\mathrm{WP}_{\mathrm{P}}\right.$ from a given treatment with a $\mathrm{P}$ fertilization rate $-\mathrm{WP}_{\mathrm{P}}$ from the treatment with no $\mathrm{P}$ fertilization) $\left[\mathrm{mg} \operatorname{pot}^{-1}\right] / \mathrm{P}$ rate applied $\left[\mathrm{mg} \mathrm{pot}^{-1}\right]^{\star} 100$.

\section{Statistical analysis}

The experimental data for each soil $\left(\mathrm{F}_{\text {Clayey }}\right.$ or $\left.\mathrm{F}_{\text {Sandy }}\right)$ were analyzed individually using the GENES ${ }^{\circledast}$ statistical packages (Cruz 2013). For an analysis of the model assumptions, Lilliefors' test for normality, and Bartlett's test for homogeneity of variance were performed. Skewness and kurtosis coefficients were also evaluated. Since all assumptions required for analysis of variance (ANOVA) were met, the F-test was performed. When the ANOVA resulted in a significant $P$-value $(P \leq 0.05)$, the means of quantitative attributes ( $\mathrm{P}$ rates) were adjusted by linear, quadratic, and quadratic base of square root models of linear regression, using the $\mathrm{SAEG}^{\circledR}$ statistical packages (Euclydes 1997). The coefficients of the adjusted models were assessed using the F-test (at significance levels of $P<0.001$, $P<0.01$, and $P<0.05)$ considering the mean square error of the ANOVA. Finally, among two or more models with significant coefficients, the one with the higher simple or multiple coefficient of determination $\left(\mathrm{r}^{2}\right.$ or $\mathrm{R}^{2}$, respectively) was chosen. After that, the critical $\mathrm{P}$ fertilization rate $\left(\mathrm{P}_{\text {Critical }}\right)$ was defined, which was determined by the intercept of the fitted curve with $90 \%$ of the maximum $\mathrm{WP}_{\mathrm{DM}}$. For qualitative attributes (soil bulk densities), Tukey's test $(P>0.05)$ was used for multiple comparisons of the means. Additionally, the Pearson's correlation coefficient (r) was calculated (at significance levels of $P<0.001, P<0.01$, and $P<0.05)$ between plant variables.

\section{Results and discussion}

\section{Biomass production}

Phosphorus rates increased $\mathrm{R}_{\mathrm{DM}}, \mathrm{S}_{\mathrm{DM}}$ and $\mathrm{WP}_{\mathrm{DM}}$ of eucalypt plants in both soils for all soil bulk densities (Table 2 and Figure 1). In the $\mathrm{F}_{\text {Clayey }}$ soil, greater increases of DM production were obtained in uncompacted $\left(\mathrm{D}_{0.90}\right)$ and moderately compacted $\left(\mathrm{D}_{1.10}\right)$ soils, while the heavily compacted soil $\left(\mathrm{D}_{1.30}\right)$ resulted in a lower degree of response to $P$ rates. In turn, in the $F_{\text {Sandy }}$ soil, greater increases of $S_{D M}$ and $\mathrm{WP}_{\mathrm{DM}}$ - in response to $\mathrm{P}$ rates - were obtained in the uncompacted soil $\left(\mathrm{D}_{1.35}\right)$.

The $\mathrm{P}_{\text {Critical }}$, corresponding to $90 \%$ of the maximum $\mathrm{WP}_{\mathrm{DM}}$, did not significantly change in response to the compaction levels, for each soil type (Table 3). The $\mathrm{P}_{\text {Critical }}$ was on average 371 and $288 \mathrm{mg} \mathrm{kg}^{-1}$ for $\mathrm{F}_{\text {Clayey }}$ and $\mathrm{F}_{\text {Sandy }}$ soil types, respectively. Therefore, the sandy soil required a lower $\mathrm{P}$ rate than the clayey one, as was expected based on the lowest maximum $\mathrm{P}$ adsorption capacity (MPAC) of the former (Table 1).

There was an interaction between the $P$ rate and soil bulk density factors for $R_{D M}, S_{D M}$ and $\mathrm{WP}_{\mathrm{DM}}$ (except for $\mathrm{R}_{\mathrm{DM}} / \mathrm{F}_{\text {Sandy }}$ ) (Table 2 ). In the $\mathrm{F}_{\text {Clayey }}$ soil, the heavily compacted soil $\left(\mathrm{D}_{1.30}\right)$ reduced $\mathrm{S}_{\mathrm{DM}}$ by 81,27 and $33 \%$, respectively, for $\mathrm{P}_{150}, \mathrm{P}_{300}$ and $\mathrm{P}_{600}$, compared with the average of $\mathrm{D}_{0.90}$ and $\mathrm{D}_{1.10}$ (which were not significantly different) (Figure 1). For $\mathrm{WP}_{\mathrm{DM}}$, the respective reductions were 81,29 and $35 \%$, and for $R_{D M}$, they were 82,48 (comparison only with $\mathrm{D}_{0.90}$ ) and $47 \%$. In turn, in the $\mathrm{F}_{\text {Sandy }}$ soil, the moderately and heavily compacted soils $\left(\mathrm{D}_{1.55}\right.$ and $\mathrm{D}_{1.75}$, respectively) did not differ from each other for $\mathrm{S}_{\mathrm{DM}}$ and $\mathrm{WP}_{\mathrm{DM}}$ (except for $\mathrm{P}_{0}$ ), and they 


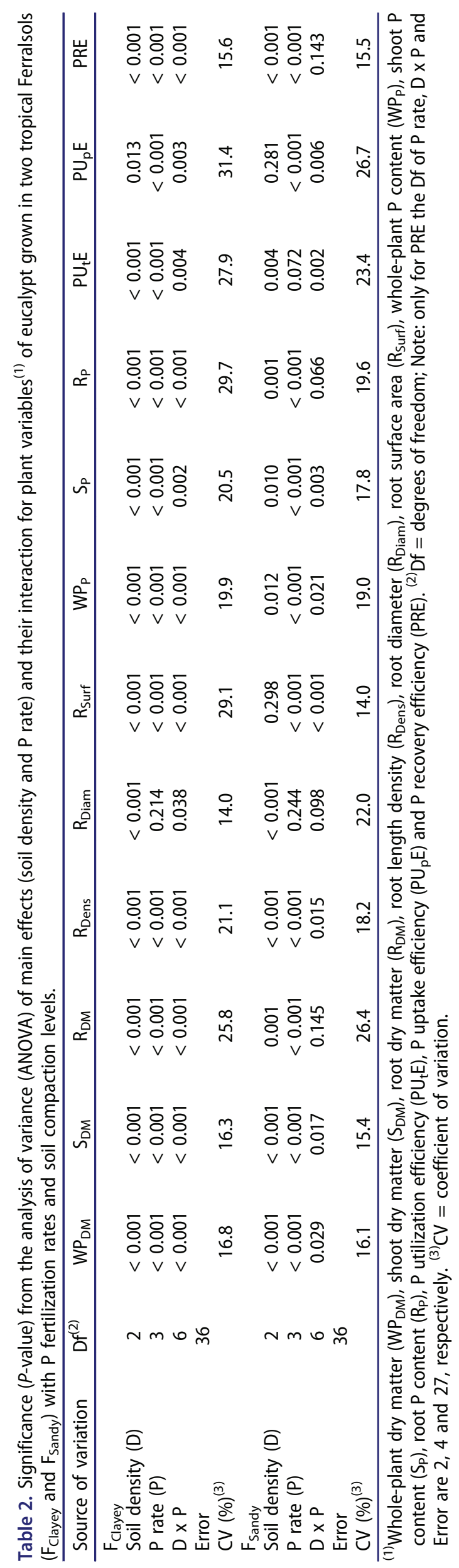



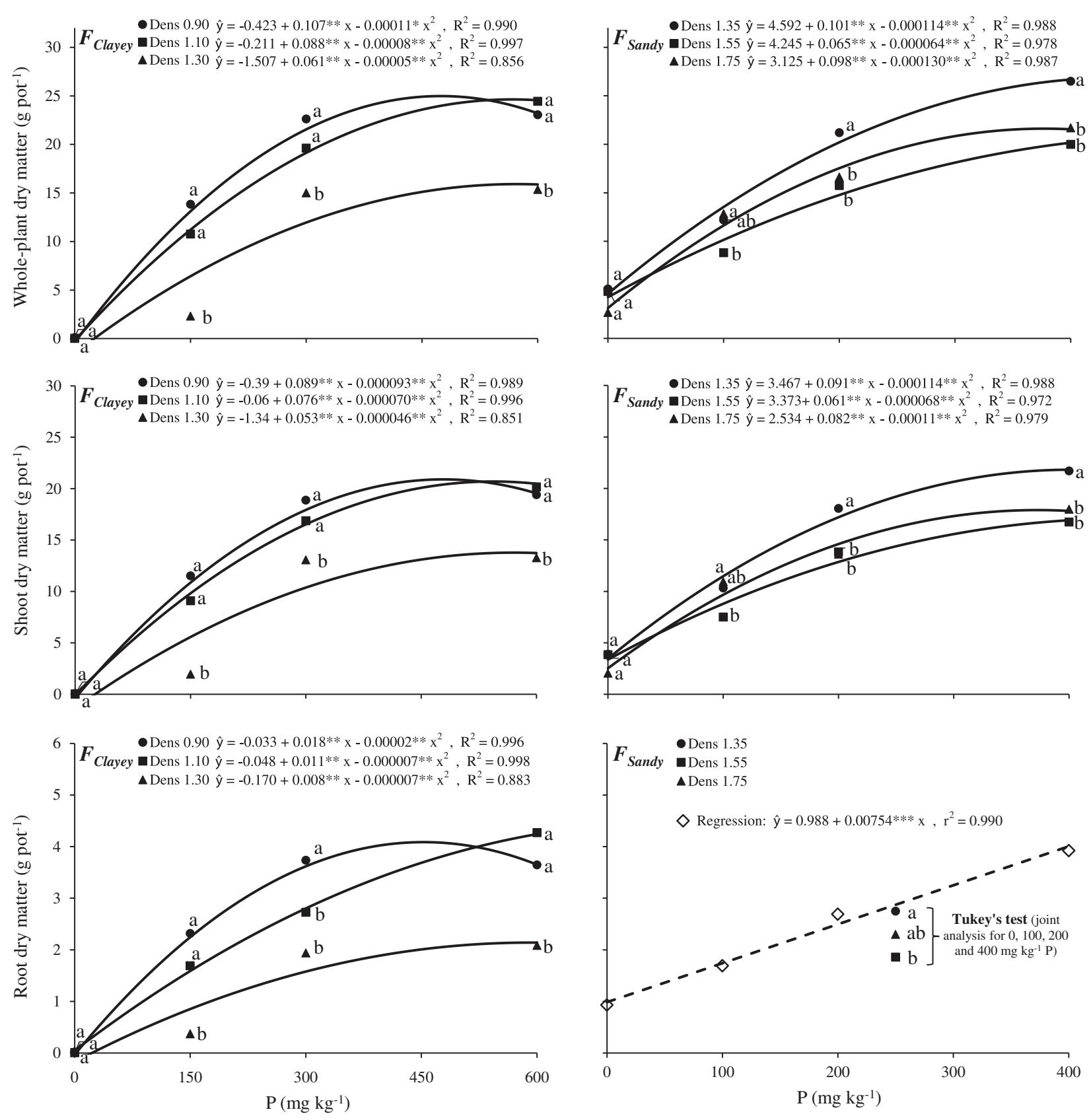

Figure 1. Whole-plant, shoot and root dry matter of eucalypt grown in two tropical Ferralsols $\left(F_{\text {Clayey }}\right.$ and $\left.F_{\text {Sandy }}\right)$ with $P$ fertilization rates and soil compaction levels. Individually for each $P$ rate, means followed by the same letters indicate not statistically different values among soil bulk densities (Tukey's test, $P>0.05$ ).

reduced $\mathrm{S}_{\mathrm{DM}}$ from 20 to $24 \%\left(\mathrm{P}_{400}\right.$ and $\mathrm{P}_{200}$, respectively), and $\mathrm{WP}_{\mathrm{DM}}$ from 21 to $24 \%\left(\mathrm{P}_{400}\right.$ and $\mathrm{P}_{200}$, respectively). Finally, the moderately compacted soil $\left(\mathrm{D}_{1.55}\right)$ reduced $\mathrm{R}_{\mathrm{DM}}$ by $32 \%$ in the F Sandy soil.

Based on these results, we observed that the $\mathrm{P}$ fertilization offset the negative effects of a moderate compaction level $\left(\mathrm{D}_{1.10}\right)$ on plant growth $\left(\mathrm{R}_{\mathrm{DM}}, \mathrm{S}_{\mathrm{DM}}\right.$ and $\left.\mathrm{WP}_{\mathrm{DM}}\right)$ in the $\mathrm{F}_{\text {Clayey }}$ soil (except for $\mathrm{R}_{\mathrm{DM}}$ at $\left.\mathrm{P}_{300}\right)$. However, this was not verified in the other levels of compaction $\left(\mathrm{D}_{1.30} / \mathrm{F}_{\text {Clayey }}\right.$; and $\mathrm{D}_{1.55}$ and $\mathrm{D}_{1.75} /$ $\left.\mathrm{F}_{\text {Sandy }}\right)$, with a few exceptions in the $\mathrm{F}_{\text {Sandy }}$ soil $\left(\mathrm{P}_{100}\right.$ for $\mathrm{S}_{\mathrm{DM}}$ and $\mathrm{WP}_{\mathrm{DM}}$; average $\mathrm{P}$ for $\left.\mathrm{R}_{\mathrm{DM}}\right)$. Similar results were found by Barzegar et al. (2006), who verified that the addition of $\mathrm{P}$ partially offset the decline of dry matter and root length of clover caused by soil compaction. According to those authors, the root length reached its maximum in the treatments receiving a high rate of $\mathrm{P}$ with low compaction; however, this compensatory effect of $\mathrm{P}$ was absent at the highest soil compaction level. 
Table 3. Root, shoot and whole-plant dry matter, corresponding to maximum estimated production, and critical P fertilization rate $\left(\mathrm{P}_{\text {Critical }}\right)$ for eucalypt grown in two tropical Ferralsols $\left(\mathrm{F}_{\text {Clayey }}\right.$ and $\left.\mathrm{F}_{\text {Sandy }}\right)$ with $\mathrm{P}$ fertilization rates and soil compaction levels.

\begin{tabular}{|c|c|c|c|c|c|}
\hline \multirow{2}{*}{$\frac{\text { Soil bulk }}{\text { density }}$} & \multicolumn{3}{|c|}{ Maximum dry matter production } & \multirow{2}{*}{$\frac{\text { Relative }}{\text { production }^{(1)}}$} & \multirow[b]{2}{*}{$\mathrm{P}_{\text {Critical }}{ }^{(2)}$} \\
\hline & Root & Shoot & Whole plant & & \\
\hline $\mathrm{g} \mathrm{cm}^{-3}$ & -—- & $-\mathrm{g} \operatorname{pot}^{-1}$ & -—-—- & $\%$ & $\overline{\mathrm{mg} \mathrm{kg}^{-1}}$ \\
\hline \multicolumn{6}{|l|}{$\mathbf{F}_{\text {Clayey }}$} \\
\hline 0.90 & $4.1 \mathrm{a}$ & 20.9a & $25.0 \mathrm{a}$ & 99.6a & $325.8 \mathrm{a}$ \\
\hline 1.10 & $4.4 a$ & $20.7 a$ & $25.1 \mathrm{a}$ & $100.0 \mathrm{a}$ & $388.1 \mathrm{a}$ \\
\hline 1.30 & $2.1 \mathrm{~b}$ & $13.8 \mathrm{~b}$ & $15.9 b$ & $63.3 b$ & $399.9 a$ \\
\hline \multicolumn{6}{|l|}{$\mathbf{F}_{\text {Sandy }}$} \\
\hline 1.35 & $5.0^{(3)} \mathrm{a}$ & $21.8 a$ & $26.8 \mathrm{a}$ & 100.0a & 288.0a \\
\hline 1.55 & $3.2^{(3)} \mathrm{b}$ & $17.1 \mathrm{~b}$ & $20.3 b$ & $75.7 b$ & $329.3 a$ \\
\hline 1.75 & $3.8 \mathrm{~b}$ & $17.9 \mathrm{~b}$ & $21.7 b$ & $81.0 \mathrm{~b}$ & $248.0 a$ \\
\hline
\end{tabular}

${ }^{(1)}$ Relative production in relation to the highest whole-plant dry matter production. ${ }^{(2)}$ Critical $\mathrm{P}$ fertilization rate corresponding to $90 \%$ of the maximum whole-plant dry matter production. ${ }^{(3)}$ Corresponding to the root dry matter production at the highest $\mathrm{P}$ rate $\left(400 \mathrm{mg} \mathrm{kg}^{-1}\right)$. Individually for each soil, means followed by the same letters within a column are not significantly different by Tukey's test $(P>0.05)$.

Soil compaction reduced the value corresponding to the maximum dry matter production $\left(\mathrm{DM}_{\mathrm{Max}}\right)$ of the roots, shoots and whole plant in both soils, but in different ways (Table 3). In the $\mathrm{F}_{\text {Clayey }}$ soil, the $\mathrm{DM}_{\mathrm{Max}}$ was similar between $\mathrm{D}_{0.90}$ and $\mathrm{D}_{1.10}$, whose average was significantly higher than that observed in $\mathrm{D}_{1.30}$ (heavily compacted soil), which had reductions of root, shoot and whole-plant $\mathrm{DM}_{\mathrm{Max}}$ of 51,34 and $37 \%$, respectively. On the other hand, in the $\mathrm{F}_{\text {Sandy }}$ soil, the effects of compaction were already observed in the moderately compacted soil $\left(D_{1.55}\right)$, which was not significantly different to heavily compacted one $\left(D_{1.75}\right)$; these averages $\left(D_{1.55}\right.$ and $\left.D_{1.75}\right)$ of $\mathrm{DM}_{\text {Max }}$ of root, shoot and the whole plant were, respectively, 30,20 and $22 \%$ smaller than that obtained in the uncompacted soil $\left(\mathrm{D}_{1.35}\right)$. We verified that the soil compaction reduced $\mathrm{DM}_{\mathrm{Max}}$ of roots more than that for the aboveground biomass. Therefore, more $\mathrm{S}_{\mathrm{DM}}$ per unit of $\mathrm{R}_{\mathrm{DM}}$ was produced in the compacted soil. Kristoffersen and Riley (2005) obtained similar results, reporting that the plants can partially compensate for the reduced root system by increasing their uptake of water and nutrients per unit of root.

These findings demonstrate the negative effects of soil compaction on plant growth. In fact, soil compaction reduces plant growth by its adverse effects on root growth and consequent reduction of water and nutrient uptake (Głąb and Gondek 2014; Liu et al. 2015; Misra and Gibbons 1996; Nosalewicz and Lipiec 2014). This statement is reinforced by the high positive correlation of $\mathrm{S}_{\mathrm{DM}}$ with $\mathrm{R}_{\text {Dens }}(\mathrm{r}=0.85)$ and $\mathrm{R}_{\text {Surf }}(\mathrm{r}=0.81)$ (Table 4). Similar correlations $(\mathrm{r}=0.74$ and 0.79 , respectively) were obtained by Chen et al. (2014) in their study with eight Lupinus angustifolius genotypes grown in field conditions.

Table 4. Pearson's correlation coefficient $(r)$ between the plant variables ${ }^{(1)}$ of eucalypt grown in two tropical Ferralsols $\left(F_{\text {Clayey }}\right.$ and $\mathrm{F}_{\text {Sandy }}$ ) with $\mathrm{P}$ fertilization rates and soil compaction levels.

\begin{tabular}{|c|c|c|c|c|c|c|c|c|c|c|c|}
\hline Variable & $W P_{D M}$ & $\mathrm{~S}_{\mathrm{DM}}$ & $\mathrm{R}_{\mathrm{DM}}$ & $\mathrm{R}_{\text {Dens }}$ & $\mathrm{R}_{\text {Diam }}$ & $\mathrm{R}_{\text {Surf }}$ & $W P_{P}$ & $S_{P}$ & $\mathrm{R}_{\mathrm{p}}$ & $\mathrm{PU}_{\mathrm{t}} \mathrm{E}$ & $\mathrm{PU}_{\mathrm{p}} \mathrm{E}$ \\
\hline$S_{D M}$ & $0.99 * * *$ & & & & & & & & & & \\
\hline $\mathrm{R}_{\mathrm{DM}}$ & $0.96^{* * *}$ & $0.94^{* * *}$ & & & & & & & & & \\
\hline $\mathrm{R}_{\text {Dens }}$ & $0.86^{* * *}$ & $0.85^{* * *}$ & $0.85^{* * *}$ & & & & & & & & \\
\hline $\mathrm{R}_{\text {Diam }}$ & $-0.08^{\mathrm{ns}}$ & $-0.08^{\mathrm{ns}}$ & $-0.08^{\mathrm{ns}}$ & $-0.21^{*}$ & & & & & & & \\
\hline $\mathrm{R}_{\text {Surf }}$ & $0.82^{* * *}$ & $0.81^{* * *}$ & $0.82^{* * *}$ & $0.91^{* * *}$ & $0.13^{\mathrm{ns}}$ & & & & & & \\
\hline$W P_{P}$ & $0.84^{* * *}$ & $0.84^{* * *}$ & $0.84^{* * *}$ & $0.78^{* * *}$ & $-0.05^{\mathrm{ns}}$ & $0.77^{* * *}$ & & & & & \\
\hline$S_{P}$ & $0.84^{* * *}$ & $0.84^{* * *}$ & $0.83^{* * *}$ & $0.78^{* * *}$ & $-0.05^{\mathrm{ns}}$ & $0.77^{* * *}$ & $0.99 * * *$ & & & & \\
\hline $\mathrm{R}_{\mathrm{p}}$ & $0.80^{* * *}$ & $0.78^{* * *}$ & $0.85^{* * *}$ & $0.74^{* * *}$ & $-0.06^{\mathrm{ns}}$ & $0.73^{* * *}$ & $0.94^{* * *}$ & $0.92^{* * *}$ & & & \\
\hline $\mathrm{PU}_{\mathrm{t}} \mathrm{E}$ & $0.74^{* * *}$ & $0.74^{* * *}$ & $0.69^{* * *}$ & $0.60^{* * *}$ & $-0.10^{\mathrm{ns}}$ & $0.54^{* * *}$ & $0.29 * * *$ & $0.29 * *$ & $0.30^{* * *}$ & & \\
\hline $\mathrm{PU}_{\mathrm{p}} \mathrm{E}$ & $0.76^{* * *}$ & $0.77^{* * *}$ & $0.69^{* * *}$ & $0.53^{* * *}$ & $-0.12^{\mathrm{ns}}$ & $0.47^{* * *}$ & $0.83^{* * *}$ & $0.84^{* * *}$ & $0.74^{* * *}$ & $0.30^{* *}$ & \\
\hline PRE & $0.30^{* *}$ & $0.30^{* *}$ & $0.31^{* *}$ & $0.53^{* * *}$ & $-0.15^{\mathrm{ns}}$ & $0.47^{* * *}$ & $0.50^{* * * *}$ & $0.52^{* * *}$ & $0.35^{* * *}$ & $-0.14^{\mathrm{ns}}$ & $0.29 * *$ \\
\hline
\end{tabular}

${ }^{(1)}$ Whole-plant dry matter $\left(W P_{D M}\right)$, shoot dry matter $\left(S_{D M}\right)$, root dry matter $\left(R_{D M}\right)$, root length density $\left(R_{\text {Dens }}\right)$, root diameter $\left(R_{\text {Diam }}\right)$, root surface area $\left(R_{\text {Surf }}\right)$, whole-plant $P$ content $\left(W P_{P}\right)$, shoot $P$ content $\left(S_{P}\right)$, root $P$ content $\left(R_{P}\right)$, $P$ utilization efficiency $\left(P U_{t} E\right)$, $P$ uptake efficiency $\left(\mathrm{PU}_{\mathrm{p}} \mathrm{E}\right)$ and $\mathrm{P}$ recovery efficiency (PRE). ${ }^{\mathrm{ns},{ }^{*},{ }^{* *}}$ and ${ }^{* * * *}$ : not significant, significant at $P>0.05, P>0.01$ and $P>0.001$ by t-test, respectively ( $n=96$ pairs of records for each correlation, except for PRE with 72 pairs). 


\section{Root growth attributes}

Phosphorus rates increased $\mathrm{R}_{\text {Dens }}$ in all bulk densities of both soils, but the magnitude of the response was lower in heavily compacted soils $\left(\mathrm{D}_{1.30} / \mathrm{F}_{\text {Clayey }}\right.$ and $\left.\mathrm{D}_{1.75} / \mathrm{F}_{\text {Sandy }}\right)$ (Table 2 and Figure 2$)$. The maximum $\mathrm{R}_{\text {Dens }}$ estimated from the regression equations (within the sample space of the experiments) were obtained by $\mathrm{P}$ rates of 385,418 and $420 \mathrm{mg} \mathrm{kg}^{-1}$ in the $\mathrm{F}_{\text {Clayey }}$ soil, respectively, for $\mathrm{D}_{0.90}, \mathrm{D}_{1.10}$ and

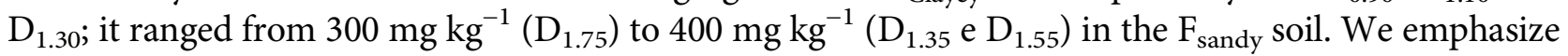
that, in the $\mathrm{F}_{\text {Sandy }}$ soil higher $\mathrm{R}_{\text {Dens }}$ could have been obtained in $\mathrm{D}_{1.35}$ and $\mathrm{D}_{1.55}$ if higher $\mathrm{P}$ rates had been used, because there was a linear response to $P$ rates in these two soil densities. On the other hand, in the heavily compacted soil $\left(D_{1.75}\right)$, the quadratic response to $P$ rates suggests that the mechanical resistance caused by soil compaction - was more restrictive on root growth than $\mathrm{P}$ availability; therefore, higher rates of $\mathrm{P}$ may not have increased $\mathrm{R}_{\text {Dens }}$ in this case.
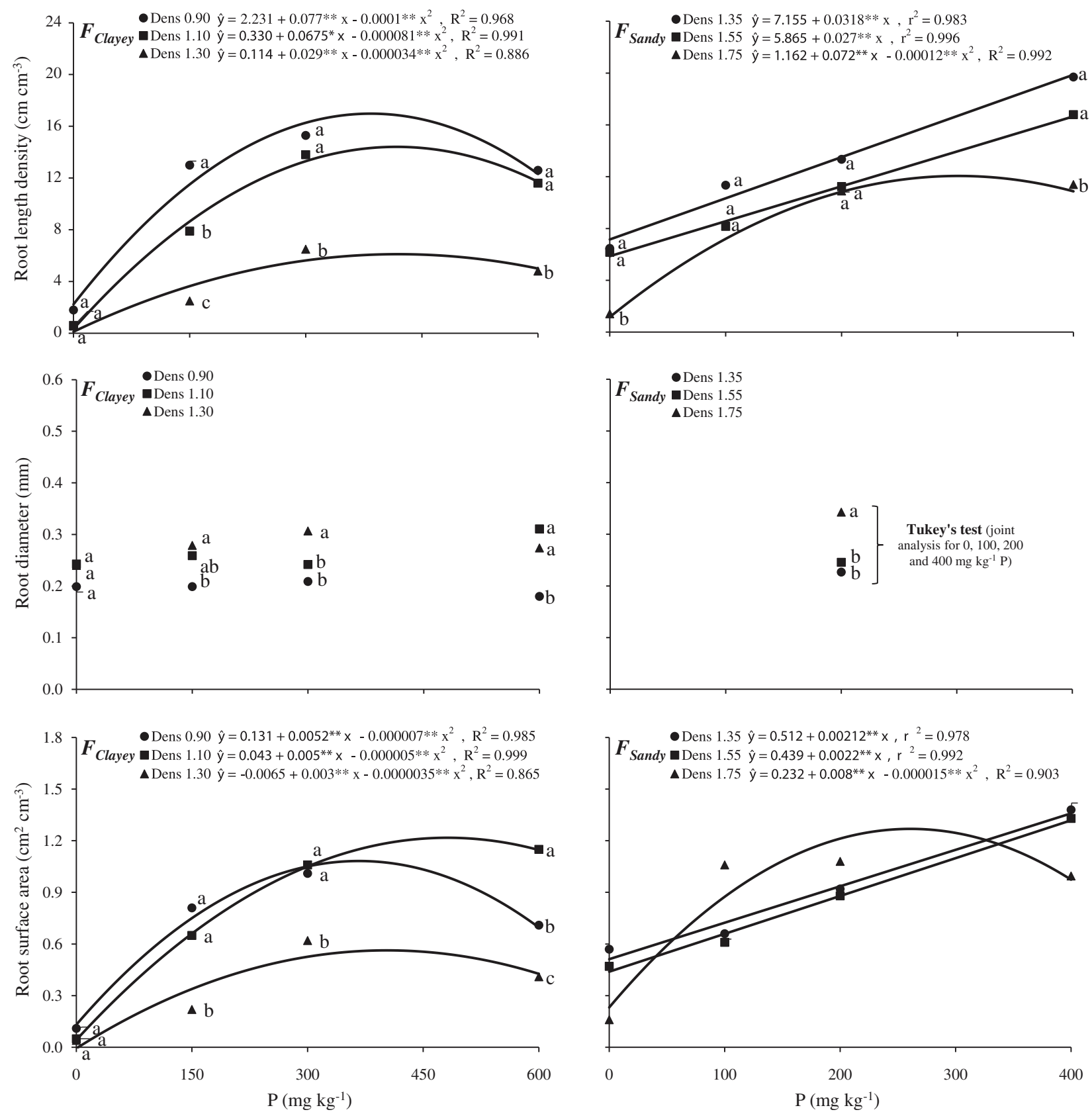

Figure 2. Root length density, root diameter and root surface area of eucalypt grown in two tropical Ferralsols $\left(F_{\text {Clayey }}\right.$ and $\left.F_{\text {Sandy }}\right)$ with $\mathrm{P}$ fertilization rates and soil compaction levels. Individually for each $\mathrm{P}$ rate, means followed by the same letters indicate not statistically different values among soil bulk densities (Tukey's test, $P>0.05$ ). 
When analyzing the effects of soil compaction, separately for each $\mathrm{P}$ rate, on $\mathrm{R}_{\text {Dens }}$, there were no effects of the moderate level of compaction $\left(\mathrm{D}_{1.10} / \mathrm{F}_{\text {Clayey }}\right.$ and $\left.\mathrm{D}_{1.55} / \mathrm{F}_{\text {Sandy }}\right)$ on $\mathrm{R}_{\text {Dens }}$ in most cases (except for $\left.\mathrm{P}_{150} / \mathrm{F}_{\text {Clayey }}\right)$ (Figure 2). However, the heavily compacted soils $\left(\mathrm{D}_{1.30} / \mathrm{F}_{\text {Clayey }}\right.$ and $\left.\mathrm{D}_{1.75} / \mathrm{F}_{\text {Sandy }}\right)$ significantly decreased $\mathrm{R}_{\text {Dens }}$ (except for $\mathrm{P}_{0} / \mathrm{F}_{\text {Clayey }}$, and $\mathrm{P}_{100}$ and $\mathrm{P}_{200} / \mathrm{F}_{\text {Sandy }}$ ). Therefore, the root growth bore the negative effects of soil compaction to a certain degree, corroborating results obtained by other researchers with eucalypt (Misra and Gibbons 1996; Silva, Barros, and Vilas Boas 2006), clover (Nadian et al. 1996), vetiver grass (Liu et al. 2015), barley (Kristoffersen and Riley 2005), and several other cereals (wheat, rye, triticale and maize; Lipiec et al. 2012).

The inhibition of root growth in compacted soils is due to several factors. In dry soils, the increase of mechanical strength and the decrease of soil water potential may be more important, while in wet soils, the main factors are oxygen $\left(\mathrm{O}_{2}\right)$ deficiency and ethylene and phytotoxin accumulation (Bengough et al. 2011; Hussain et al. 2000; Lynch, Marschner, and Rengel 2012; Nosalewicz and Lipiec 2014). In this context, Benigno et al. (2012) affirmed that the soil physical strength, rather than the excess of ethylene, reduced root elongation of Eucalyptus todtiana seedlings in mechanically compacted sandy soils. The reduction of root growth is intensified by the accumulation of carbon dioxide $\left(\mathrm{CO}_{2}\right)$ and low $\mathrm{O}_{2}$ diffusion into the soil atmosphere (Tracy et al. 2011). The accumulation of $\mathrm{CO}_{2}$ and the lack of $\mathrm{O}_{2}$ also reduce the permeability of the roots to water (Opik and Rolfe 2005), with negative consequences on plant growth. Hernandez-Ramirez et al. (2014) ascribed the reduction of root growth under increasing soil compaction to the restrictions on $\mathrm{O}_{2}$ diffusion, since the volume of soil pores larger than the average $\mathrm{R}_{\text {Diam }}$ was much lower under the heaviest compacted soil than in the loosened one.

Phosphorus rates did not significantly change the $\mathrm{R}_{\text {Diam }}$ (Table 2). On the other hand, soil compaction increased the $\mathrm{R}_{\text {Diam }}$ in both soils (except for $\mathrm{P}_{0} / \mathrm{F}_{\text {Clayey }}$ ) (Table 2 and Figure 2). In the $\mathrm{F}_{\text {Sandy }}$ soil, the heavily compacted soil $\left(\mathrm{D}_{1.75}\right)$ increased the $\mathrm{R}_{\text {Diam }}$ by $42 \%$ compared with the other treatments $\left(D_{1.35}\right.$ and $\left.D_{1.55}\right)$. In turn, in the $F_{\text {Clayey }}$ soil, there was an interaction between $P$ rate and soil density factors. The heavily compacted soil $\left(D_{1.30}\right)$, compared to the no compacted one $\left(D_{0.90}\right)$, increased the $\mathrm{R}_{\text {Diam }}$ by 40,48 and $50 \%$ in the $\mathrm{P}$ rates of $\mathrm{P}_{150}, \mathrm{P}_{300}$ and $\mathrm{P}_{600}$, respectively. However, there was no effect of soil compaction on the $R_{\text {Diam }}$ at $P_{0}$. Finally, while $D_{1.10}$ did not change $R_{\text {Diam }}$ at $\mathrm{P}_{150}$ and $\mathrm{P}_{300}$, it increased it by $72 \%$ at $\mathrm{P}_{600}$.

These results of soil compaction increasing $\mathrm{R}_{\text {Diam }}$ confirm previous research recorded in the literature with other plant species. Liu et al. (2015) also obtained an increase of $\mathrm{R}_{\text {Diam }}$ of around $46 \%$ in vetiver grass (Vetiveria zizanioides) in response to a soil bulk density increment from 1.20 to $1.58 \mathrm{~g} \mathrm{dm}^{-3}$. In turn, Valadão et al. (2015) observed an increase of $67 \%$ in maize $\mathrm{R}_{\text {Diam }}$ caused by an increment of soil bulk density from 1.15 to $1.33 \mathrm{~g} \mathrm{dm}^{-3}$. Similar results were found by other researchers for woody species (Alameda and Villar 2012), barley (Hernandez-Ramirez et al. 2014; Kristoffersen and Riley 2005) and tomato (Tracy et al. 2012). In compacted soils, the roots undergo physiological and morphological modifications, becoming short, thick and scaly, and with a thick cell wall, having less malleability to deviate from those points of greater resistance in the soil (Alameda and Villar 2012; Misra and Gibbons 1996; Nosalewicz and Lipiec 2014; Silva et al. 2002). These characteristics are typical of roots that grow in a soil-reducing environment (with lowering of the soil redox potential, Eh), which can be caused by soil compaction, since it can reduce water drainage and, consequently, induce anaerobic conditions or hypoxia (Misra and Gibbons 1996).

As reviewed by Clark, Whalley, and Barraclough (2003), the increases in $\mathrm{R}_{\text {Diam }}$ seem to be the key plant response for root growth through soil layers with high penetration resistance. The roots will penetrate compacted soils when the soil pore diameter is larger than the $\mathrm{R}_{\text {Diam }}$, or smaller if it is not so rigid. Reinforcing this statement, Hernandez-Ramirez et al. (2014) obtained significant correlations of soil macroporosity with $\mathrm{R}_{\text {Diam }}(\mathrm{r}=-0.63)$ and $\mathrm{R}_{\text {Dens }}(\mathrm{r}=0.66)$. Thus, the soil compaction can reduce the volume of soil explored by roots to acquire water and nutrients by increasing $\mathrm{R}_{\text {Diam }}$. Therefore, soil compaction and water stress can be considered as being cause-and-effect in some situations, due to the former reducing the exploration capacity of roots, thus resulting in lower water uptake (Alameda and Villar 2012). 
The $\mathrm{R}_{\text {Surf }}$ increased with increasing $\mathrm{P}$ rates in both soils (Table 2 and Figure 2). In the $\mathrm{F}_{\text {Clayey }}$ soil, the $\mathrm{P}$ rates of 366,482 and $404 \mathrm{mg} \mathrm{kg}^{-1}$ provided the largest $\mathrm{R}_{\text {Suf }}$ for $\mathrm{D}_{0.90}, \mathrm{D}_{1.10}$ and $\mathrm{D}_{1.30}$, respectively, and it ranged from $261 \mathrm{mg} \mathrm{kg}^{-1}\left(\mathrm{D}_{1.75}\right)$ up to $400 \mathrm{mg} \mathrm{kg}^{-1}\left(\mathrm{D}_{1.35}\right.$ and $\left.\mathrm{D}_{1.55}\right)$ in the $\mathrm{F}_{\text {Sandy }}$ soil. These $\mathrm{P}$ rates are very close to those previously obtained for $\mathrm{R}_{\text {Dens }}$, because $\mathrm{R}_{\text {Surf }}$ had high positive correlation with $\mathrm{R}_{\text {Dens }}(\mathrm{r}=0.91)$.

Soil compaction significantly decreased $\mathrm{R}_{\text {Surf }}$ only in the $\mathrm{F}_{\text {Clayey }}$ soil (Table 2 and Figure 2). For most $P$ rates $\left(0,150\right.$ and $\left.300 \mathrm{mg} \mathrm{kg}^{-1}\right)$, there were no differences between the $\mathrm{R}_{\text {Surf }}$ from $\mathrm{D}_{0.90}$ and $D_{1.10}$. However, the heavily compacted soil $\left(D_{1.30}\right)$ reduced $R_{\text {Surf }}$ by 73,39 and $42 \%$ for $P_{150}, P_{300}$ and $\mathrm{P}_{600}$, respectively. The value of $\mathrm{R}_{\text {Surf }}$ is the product of $\mathrm{R}_{\text {Dens }}$ and $\mathrm{R}_{\text {Diam }}$, which were distinctly influenced by soil compaction and $\mathrm{P}$ rates. Liu et al. (2015) verified an $\mathrm{R}_{\text {Surf }}$ decrease of $51 \%$ in vetiver grass when the soil bulk density increased from 1.20 to $1.58 \mathrm{~g} \mathrm{dm}^{-3}$ in a sandy loam soil, reinforcing the negative effects of soil compaction on root growth.

Phosphorus rates increased $R_{\text {Dens }}$ and $R_{\text {Surf }}$ (Figure 2) similarly to that found for $R_{D M}$, since there were high and significant correlations of $R_{D M}$ with $R_{\text {Dens }}$ and $R_{\text {Surf }}(r=0.85$ and 0.82 , respectively) (Table 4). These increases of $\mathrm{R}_{\text {Surf }}$ and $\mathrm{R}_{\text {Dens }}$ may have contributed to better uptake of water and nutrients by the plant and to its growth. This was also found by Nosalewicz and Lipiec (2014), whose results indicated the occurrence of a significant positive correlation between the root water uptake rate and the root length of thin $(<0.43 \mathrm{~mm})$ and medium diameter $(0.48-0.65 \mathrm{~mm})$ roots, unless the soil was heavily compacted.

\section{Phosphorus content in plants}

As expected, $\mathrm{R}_{\mathrm{P}}, \mathrm{S}_{\mathrm{P}}$ and $\mathrm{WP}_{\mathrm{P}}$ increased in response to $\mathrm{P}$ rates (Table 2 and Figure 3 ). The largest $\mathrm{P}$ rate $\left(600\right.$ or $400 \mathrm{mg} \mathrm{kg}^{-1}$, respectively in the $\mathrm{F}_{\text {Clayey }}$ and $\mathrm{F}_{\text {Sandy }}$ soil types) provided the highest $\mathrm{P}$ content in the plant due its promotion of higher $\mathrm{P}$ availability in the soil solution.

The levels of soil compaction influenced the $\mathrm{P}$ uptake by plants in a different manner between the soils. In the $\mathrm{F}_{\text {Sandy }}$ soil, there were no effects of increased soil bulk density on $\mathrm{P}$ uptake, except in a few situations: $D_{1.55}$ decreased $\mathrm{WP}_{\mathrm{P}}$ and $\mathrm{S}_{\mathrm{P}}$ at $\mathrm{P}_{400}$, and decreased $\mathrm{R}_{\mathrm{P}}$ for all $\mathrm{P}$ rates (Figure 3 ). On the other hand, in the $\mathrm{F}_{\text {Clayey }}$ soil, there were no effects of the moderate level of soil compaction $\left(\mathrm{D}_{1.10}\right)$ on $\mathrm{WP}_{\mathrm{P}}, \mathrm{S}_{\mathrm{P}}$ and $\mathrm{R}_{\mathrm{P}}$ (except for $\mathrm{R}_{\mathrm{P}}$ at $\mathrm{P}_{150}$ ), but in the treatments with heavily compacted soils $\left(D_{1.30}\right)$ there were reductions of $P$ uptake in most of the treatments (except for $P_{0}$, and for $S_{P}$ at $P_{300}$ ).

Similar results were obtained by other authors (Ahmad, Hassan, and Belford 2009; Barzegar et al. 2006; Nadian et al. 1996) who verified that the $\mathrm{WP}_{\mathrm{P}}$ was reduced by soil compaction. According to these studies, this is a direct consequence of the lower root growth and the reduction of $\mathrm{P}$ diffusive flux. Novais and Smyth (1999) reported that soil compaction increases the interaction between phosphate ions and the surface of the colloids along their diffusion trajectory; in this manner, phosphate diffuses ever closer to positively charged surfaces, which adsorb it, reducing the $\mathrm{P}$ availability in the soil solution. This $\mathrm{P}$ adsorption in the surface of the colloids is more problematic in highly weathered acidic soils, such as the ones used in this present study, because they have high $\mathrm{P}$ adsorption capacity, mainly the ones with oxidic mineralogy and clayey texture (Bastos et al. 2008). In this context, Silva et al. (2018) verified a decrease of $\mathrm{P}$ diffusive flux by $83 \%$ in a clayey oxidicgibbsitic Ferralsol (a highly weathered acid Brazilian soil) in response to the soil compaction, reinforcing this statement. According to Arvidsson (1999), the uptake of nutrients transported by diffusion is more affected by soil compaction than nutrients transported by mass flow. Further, the deficiency of $\mathrm{O}_{2}$ in compacted soils results in reduced root respiration, altering the metabolism and, therefore, reducing the nutrient uptake by the plant (Nadian et al. 1996).

The average $\mathrm{WP}_{\mathrm{P}}$ in the $\mathrm{F}_{\text {Sandy }}$ soil $\left(43.8 \mathrm{mg}\right.$ pot $^{-1}$ ) was $108.6 \%$ higher than in the $\mathrm{F}_{\text {Clayey }}$ soil $\left(21 \mathrm{mg} \mathrm{pot}^{-1}\right)$, reflecting the greater $\mathrm{P}$ availability in the sandy soil, although the clayey soil had a $50 \%$ greater $\mathrm{P}$ rate. This result was expected because the $\mathrm{F}_{\text {Sandy }}$ soil has lower MPAC (Table 1), which is an indirect measurement of the P buffering capacity (Novais and Kamprath 1979). The buffering capacity can be understood as the soil resistance to changes in P solution concentration, when $\mathrm{P}$ is 

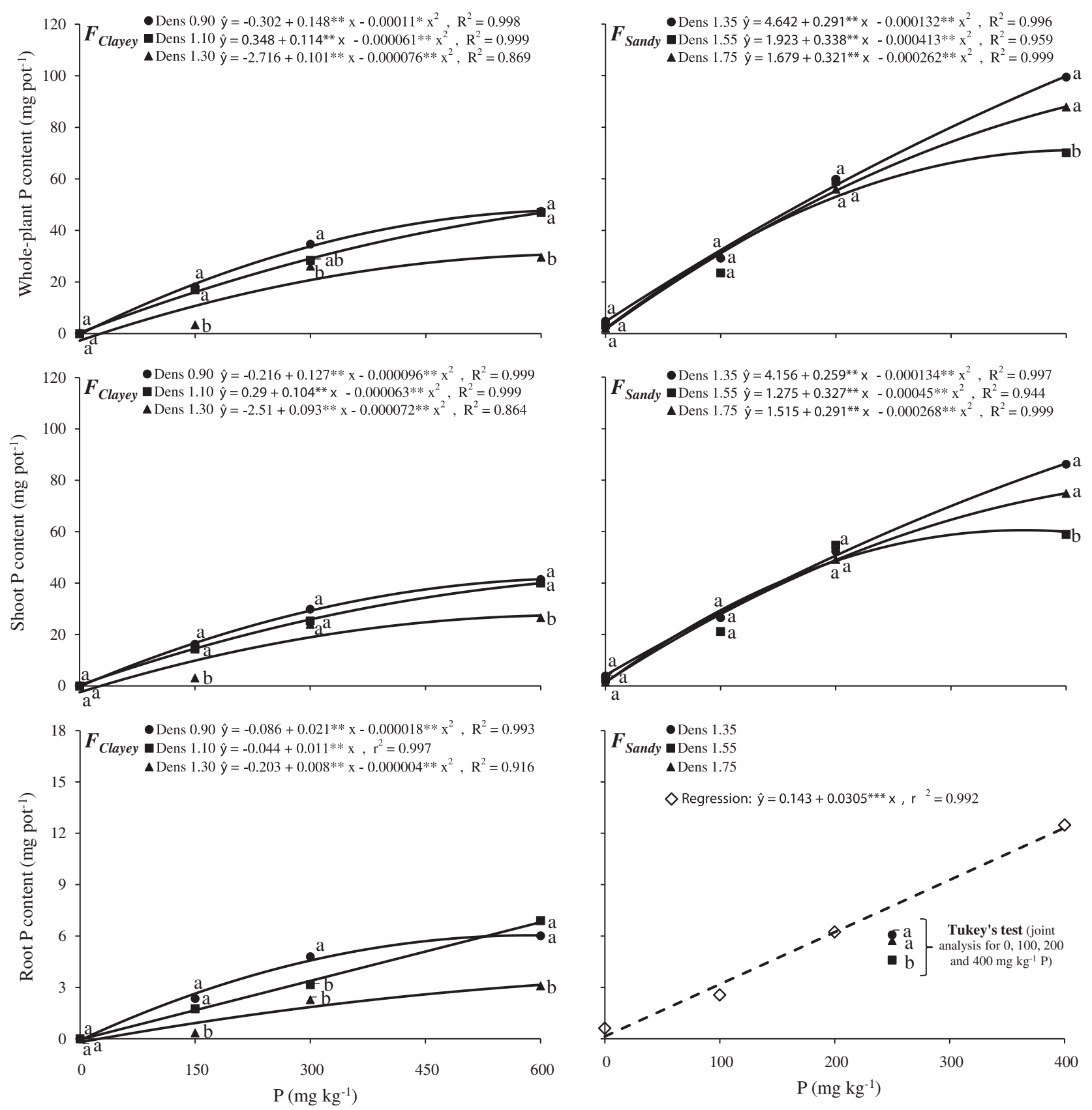

Figure 3. Whole-plant, shoot and root $P$ contents of eucalypt grown in two tropical Ferralsols $\left(F_{\text {Clayey }}\right.$ and $\left.F_{\text {Sandy }}\right)$ with $P$ fertilization rates and soil compaction levels. Individually for each $P$ rate, means followed by the same letters indicate not statistically different values among soil bulk densities (Tukey's test, $P>0.05$ ).

added or withdrawn from the soil. This comparison between soil textures was also done by Kristoffersen and Riley (2005), who reported that barley plants grown on a loam soil had more than twice as much $\mathrm{P}$ uptake compared to plants grown on clay loam and silt soils.

\section{Phosphorus nutritional efficiency indexes}

Phosphorus rates increased $\mathrm{PU}_{\mathrm{t}} \mathrm{E}$ only in the $\mathrm{F}_{\text {Clayey }}$ soil (Table 2 and Figure 4). Higher $\mathrm{PU}_{\mathrm{t}} \mathrm{E}$ values were obtained with the $\mathrm{P}$ rates of 389,447 and $515 \mathrm{mg} \mathrm{kg}^{-1}$ in $\mathrm{D}_{0.90}, \mathrm{D}_{1.10}$ and $\mathrm{D}_{1.30}$, respectively.

The moderate levels of soil compaction $\left(\mathrm{D}_{1.10} / \mathrm{F}_{\text {Clayey }}\right.$ and $\left.\mathrm{D}_{1.55} / \mathrm{F}_{\text {Sandy }}\right)$ did not change the $\mathrm{PU}_{\mathrm{t}} \mathrm{E}$ (except for $\left.\mathrm{P}_{200} / \mathrm{F}_{\text {Sandy }}\right)$ (Figure 4 ). However, the heavily compacted soils $\left(\mathrm{D}_{1.30} / \mathrm{F}_{\text {Clayey }}\right.$ and $\mathrm{D}_{1.75} /$ 

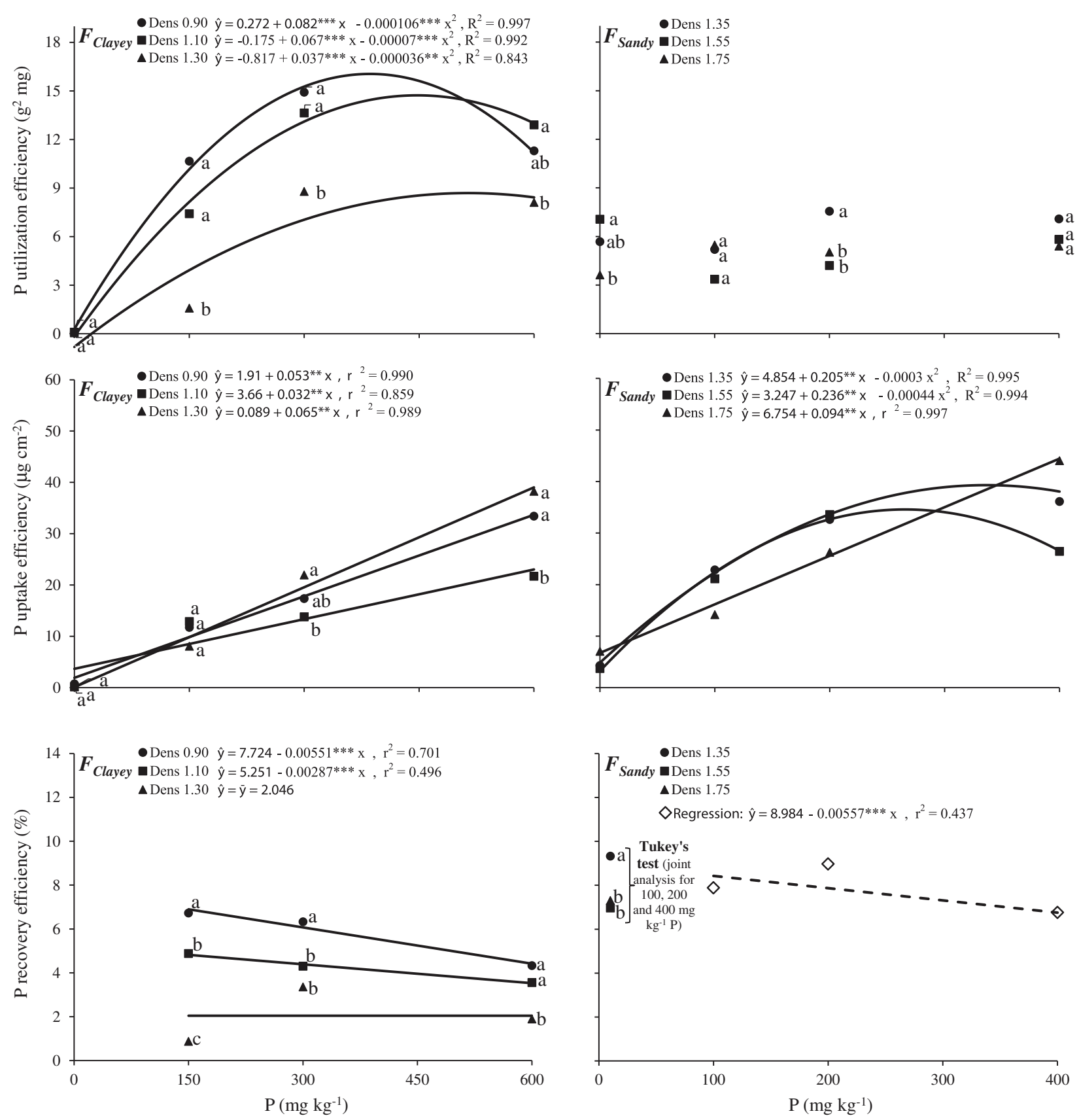

Figure 4. Phosphorus utilization efficiency, $P$ uptake efficiency and $P$ recovery efficiency of eucalypt grown in two tropical Ferralsols $\left(F_{\text {Clayey }}\right.$ and $\left.F_{\text {Sandy }}\right)$ with $P$ fertilization rates and soil compaction levels. Individually for each $P$ rate, means followed by the same letters indicate not statistically different values among soil bulk densities (Tukey's test, $P>0.05$ ).

$\mathrm{F}_{\text {Sandy }}$ ) decreased the $\mathrm{PU}_{\mathrm{t}} \mathrm{E}$ by 85,41 and $28 \%$ for $\mathrm{P}_{150}, \mathrm{P}_{300}$ and $\mathrm{P}_{600}$, respectively, in the $\mathrm{F}_{\text {Clayey }}$ soil, and by 36 and $33 \%$ for $\mathrm{P}_{0}$ and $\mathrm{P}_{200}$, respectively, in the $\mathrm{F}_{\text {Sandy }}$ soil.

The $\mathrm{PU}_{\mathrm{t}} \mathrm{E}$ was, on average, $37 \%$ higher in the $\mathrm{F}_{\text {Clayey }}$ soil than in the $\mathrm{F}_{\text {Sandy }}$ soil, due to the influence of the P buffering capacity on the P-use efficiency of the plants, since the MPAC of $\mathrm{F}_{\text {Clayey }}$ is 3.3 times greater than $\mathrm{F}_{\text {Sandy }}$ (Table 1 ).

The $\mathrm{PU}_{\mathrm{p}} \mathrm{E}$ was increased by $\mathrm{P}$ rates in both soils (Table 2 and Figure 4). The maximum $\mathrm{PU}_{\mathrm{p}} \mathrm{E}$ was obtained in the $\mathrm{F}_{\text {Sandy }}$ soil in the treatments with $\mathrm{P}$ rates of 335,266 and $400 \mathrm{mg} \mathrm{kg}^{-1}$ in $\mathrm{D}_{1.35}, \mathrm{D}_{1.55}$ and $\mathrm{D}_{1.75}$, respectively, and in the highest $\mathrm{P}$ rate $\left(\mathrm{P}_{600}\right)$ for all soil bulk densities in the $\mathrm{F}_{\text {Clayey }}$ soil. Therefore, if higher $\mathrm{P}$ rates had been used, higher $\mathrm{PU}_{\mathrm{p}} \mathrm{E}$ could have been obtained in the treatments where it increased linearly. 
The soil compaction changed the $\mathrm{PU}_{\mathrm{p}} \mathrm{E}$ only in the $\mathrm{F}_{\text {Clayey }}$ soil (Table 2 and Figure 4). The $\mathrm{PU}_{\mathrm{p}} \mathrm{E}$ increased by 59.8 and $76.6 \%$ for $\mathrm{P}_{300}$ and $\mathrm{P}_{600}$, respectively, when the soil bulk density increased from $\mathrm{D}_{1.10}$ to $\mathrm{D}_{1.30}$. These results are corroborated by Rosolem, Almeida, and Sacramento (1994), who observed that the soybean root system in compacted soil, although smaller, had higher uptakes of $\mathrm{P}$, potassium $(\mathrm{K})$, nitrogen $(\mathrm{N})$, calcium $(\mathrm{Ca})$ and magnesium $(\mathrm{Mg})$ per unit of root length. Barzegar et al. (2006), Kristoffersen and Riley (2005), and Nadian et al. (1996) also verified an increase in P uptake per unit of root length with the increase of soil compaction. To reach the root uptake sites, the nutrients are moved through the soil solution by the transport mechanisms of mass flow or diffusion, which are dependent on the particular characteristics of each soil. Due to its low concentration in the soil solution, $\mathrm{P}$ is mainly transported in the soil by diffusion (Novais and Smyth 1999). This is a very slow process, which means that the plant roots must normally be in the vicinity of the $\mathrm{P}$ source to ensure its uptake (Kristoffersen and Riley 2005). Considering that the $\mathrm{P}$ diffusive flux in the soil is more restrictive than the P root uptake rate, $\mathrm{PU}_{\mathrm{p}} \mathrm{E}$ is mainly associated with root growth, instead of the $\mathrm{P}$ influx rate through the roots. Reinforcing this statement, there were high and significant correlations of $\mathrm{PU}_{\mathrm{p}} \mathrm{E}$ with $\mathrm{R}_{\mathrm{DM}}, \mathrm{R}_{\text {Dens }}$ and $\mathrm{R}_{\text {Surf }}(\mathrm{r}=0.69$, 0.53 and 0.47 , respectively) (Table 4). Barzegar et al. (2006) concluded that increasing root length due to $\mathrm{P}$ fertilization is possibly a key tool to reduce the adverse effects of soil compaction on plant growth.

The PRE decreased with increasing $\mathrm{P}$ rates in both soils (Table 2 and Figure 4). In the $\mathrm{F}_{\text {Clayey }}$ soil, greater decreases of PRE were obtained in uncompacted $\left(\mathrm{D}_{0.90}\right)$ and moderately compacted $\left(\mathrm{D}_{1.10}\right)$ soils; while in the heavily compacted soil $\left(D_{1.30}\right)$ there was no effect of $\mathrm{P}$ rates on PRE, likely due to the strong root growth inhibition caused by soil compaction, which restricted the uptake of $\mathrm{P}$ from larger soil volume.

The soil compaction reduced the PRE in most of the situations (Table 2 and Figure 4). In the $\mathrm{F}_{\text {Sandy }}$ the PRE was, on average, 2.19 percentage points greater in the uncompacted soil $\left(\mathrm{D}_{1.35}\right)$ than that observed in the compacted soils $\left(\mathrm{D}_{1.35}\right.$ and $\left.\mathrm{D}_{1.55}\right)$. In turn, in the $\mathrm{F}_{\text {Clayey }}$ soil, there was an interaction between $\mathrm{P}$ rate and soil density factors. In the $\mathrm{P}_{150}$ treatments, the PRE decreased by 1.85 and 5.85 percentage points for $\mathrm{D}_{1.10}$ and $\mathrm{D}_{1.30}$, respectively, compared with the uncompacted soil $\left(\mathrm{D}_{0.90}\right)$. In the $\mathrm{P}_{300}$, there was no significant difference of PRE between $\mathrm{D}_{1.10}$ and $\mathrm{D}_{1.30}$ treatments, whose average was 2.5 percentage points lower than $\mathrm{D}_{0.90}$. Finally, in the $\mathrm{P}_{600}$, the PRE was 2.05 percentage points lower in the heavy compacted soil $\left(D_{1.30}\right)$, compared with the average of $D_{0.90}$ and $\mathrm{D}_{1.10}$. On average, the PRE was 2.8 times greater in $\mathrm{D}_{0.90}$ than that observed in $\mathrm{D}_{1.30}$. This may be attributed to the strong effect of soil compaction on root growth (Figure 2) reducing $\mathrm{P}$ uptake, as it can be deduced from the high positive correlation of PRE with $\mathrm{R}_{\text {Dens }}(\mathrm{r}=0.53)$ (Table 4).

The plants grown on the $\mathrm{F}_{\text {Sandy }}$ soil had, on average, twice as much PRE compared to the plants grown on $\mathrm{F}_{\text {Clayey }}$ soil, due to the influence of the $\mathrm{P}$ buffering capacity on the availability of $\mathrm{P}$ in soil solution, since the MPAC of $\mathrm{F}_{\text {Clayey }}$ soil is 3.3 times greater than $\mathrm{F}_{\text {Sandy }}$ soil (Table 1).

\section{Conclusion}

Soil compaction increased root diameter, restrained root growth and, consequently, reduced $\mathrm{P}$ uptake by eucalypt. Because of this mechanical restriction, there was a reduction in the $\mathrm{P}$ content in the plant, $\mathrm{P}$ utilization efficiency and $\mathrm{P}$ recovery efficiency. Phosphorus fertilization increases $\mathrm{P}$ availability in soil, and consequently increases root density and surface area, resulting in greater whole-plant $\mathrm{P}$ content and dry matter, as well as higher $\mathrm{P}$ utilization efficiency and $\mathrm{P}$ recover efficiency. Finally, these results verify that $\mathrm{P}$ fertilization is not effective to offset the deleterious effects of soil compaction on eucalypt growth and nutrition.

\section{ORCID}

Sérgio Ricardo Silva (D) http://orcid.org/0000-0001-6951-8324 


\section{References}

Ahmad, N., F. U. Hassan, and R. K. Belford. 2009. Effect of soil compaction in the sub-humid cropping environment in Pakistan on uptake of NPK and grain yield in wheat (Triticum aestivum). I. Compaction. Field Crops Research 110:54-60. doi:10.1016/j.fcr.2008.07.001.

Alameda, D., and R. Villar. 2012. Linking root traits to plant physiology and growth in Fraxinus angustifolia Vahl. seedlings under soil compaction. Environmental and Experimental Botany 79:49-57. doi:10.1016/j. envexpbot.2012.01.004.

Alvarez-Venegas, V. H., R. F. Novais, L. E. Dias, and J. A. Oliveira. 2000. Determination and use of the remaining phosphorus. Boletim Informativo (Sociedade Brasileira de Ciência do Solo) 25:27-32.

Arvidsson, J. 1999. Nutrient uptake and growth of barley as affected by soil compaction. Plant and Soil 208:9-19. doi:10.1023/A:1004484518652.

Barros, N. F., and R. F. Novais. 1996. Eucalypt nutrition and fertilizer regimes in Brazil. In Nutrition of eucalypts, ed. P. M. Attiwill and M. A. Adams, 335-55. Collingwood, Ontario: CSIRO Publishing.

Barzegar, A. R., H. Nadian, F. Heidari, S. J. Herbert, and A. M. Hashemi. 2006. Interaction of soil compaction, phosphorus and zinc on clover growth and accumulation of phosphorus. Soil \& Tillage Research 87:155-162. doi:10.1016/j.still.2005.03.004.

Bastos, A. L., J. P. V. Costa, I. F. Silva, R. W. C. Raposo, and J. S. Souto. 2008. Influence of phosphorus doses in diffusive flow in the soils of Alagoas. Revista Brasileira de Engenharia Agrícola e Ambiental 12:136-42. doi:10.1590/ S1415-43662008000200005.

Bejarano, M. D., R. Villar, A. M. Murillo, and J. L. Quero. 2010. Effects of soil compaction and light on growth of Quercus pyrenaica Willd. (Fagaceae) seedlings. Soil \& Tillage Research 110:108-114. doi:10.1016/j.still.2010.07.008.

Bengough, A. G., B. M. McKenzie, P. D. Hallett, and T. A. Valentine. 2011. Root elongation, water stress, and mechanical impedance: A review of limiting stress and beneficial root tip traits. Journal of Experimental Botany 62:59-68. doi:10.1093/jxb/erq350.

Benigno, S. M., G. R. Cawthray, K. W. Dixon, and J. C. Stevens. 2012. Soil physical strength rather than excess ethylene reduces root elongation of Eucalyptus seedlings in mechanically impeded sandy soils. Plant Growth Regulation 68:261-270. doi:10.1007/s10725-012-9714-2.

Chen, Y. L., J. Palta, J. Clements, B. Buirchell, K. H. M. Siddique, and Z. Rengel. 2014. Root architecture alteration of narrow-leafed lupin and wheat in response to soil compaction. Field Crops Research 165:61-70. doi:10.1016/j. fcr.2014.04.007.

Clark, L. J., W. R. Whalley, and P. B. Barraclough. 2003. How do roots penetrate strong soil? Plant and Soil 255:93-104. doi:10.1023/A:1026140122848.

Cruz, C. D. 2013. GENES - a software package for analysis in experimental statistics and quantitative genetics. Acta Scientiarum. Agronomy 35:271-276. doi:10.4025/actasciagron.v35i3.21251.

Euclydes, R. F. 1997. Manual de utilização do programa SAEG: Sistema para Análises Estatísticas e Genéticas. Viçosa, Brazil: Viçosa Federal University Press.

FAO. 2014. International soil classification system for naming soils and creating legends for soil maps. World reference base for soil resources. Rome, Italy: Food and Agriculture Organization of the United Nations.

Głąb, T., and K. Gondek. 2014. The influence of soil compaction and N fertilization on physico-chemical properties of Mollic Fluvisol soil under red clover/grass mixture. Geoderma 226-227:204-212. doi:10.1016/j.geoderma.2014.02.021.

Greenwood, D. J., K. Kubo, I. G. Burns, and A. Draycott. 1989. Apparent recovery of fertilizer N by vegetable crops. Soil Science and Plant Nutrition 35:367-381. doi:10.1080/00380768.1989.10434770.

Hernandez-Ramirez, G., E. J. Lawrence-Smith, S. M. Sinton, F. Tabley, A. Schwen, M. H. Beare, and H. E. Brow. 2014. Root responses to alterations in macroporosity and penetrability in a silt loam soil. Soil Science Society of America Journal 78:1392-1403. doi:10.2136/sssaj2014.01.0005.

Hussain, A., C. R. Black, I. B. Taylor, and J. A. Roberts. 2000. Does an antagonistic relationship between ABA and ethylene mediate shoot growth when tomato (Lycopersicon esculentum Mill.) plants encounter compacted soil? Plant, Cell and Environment 23:1217-1226. doi:10.1046/j.1365-3040.2000.00639.x.

Johnson, C. M., and A. Ulrich. 1959. Analytical methods for use in plants analyses. California Agricultural Experiment Station Bulletin 766:32-33.

Kristoffersen, A. Ø., and H. Riley. 2005. Effects of soil compaction and moisture regime on the root and shoot growth and phosphorus uptake of barley plants growing on soils with varying phosphorus status. Nutrient Cycling in Agroecosystems 72:135-146. doi:10.1007/s10705-005-0240-8.

Lipiec, J., R. Horn, J. Pietrusiewicz, and A. Siczek. 2012. Effects of soil compaction on root elongation and anatomy of different cereal plant species. Soil \& Tillage Research 121:74-81. doi:10.1016/j.still.2012.01.013.

Liu, W. G., L. X. Li, H. R. Xie, Y. Y. He, and J. X. Liu. 2015. Effect of soil bulk density on root morphology and biomass of vetiver grass seedlings. Acta Pratacultuae Sinica 24:214-220. doi:10.11686/cyxb20150425.

Lynch, J., P. Marschner, and Z. Rengel. 2012. Effect of internal and external factors on root growth and development. In Marschner's mineral nutrition of higher plants, ed. P. Marschner, 331-46. Amsterdam, Netherlands: Elsevier/ Academic Press. 
Misra, R. K., and A. K. Gibbons. 1996. Growth and morphology of eucalypt seedling-roots, in relation to soil strength arising from compaction. Plant and Soil 182:1-11. doi:10.1007/BF00010990.

Nadian, H., S. E. Smith, A. M. Alston, and R. S. Murray. 1996. The effect of soil compaction on growth and P uptake by Trifolium subterraneum: Interactions with mycorrhizal colonization. Plant and Soil 182:39-49. doi:10.1007/ BF00010993.

Nosalewicz, A., and J. Lipiec. 2014. The effect of compacted soil layers on vertical root distribution and water uptake by wheat. Plant and Soil 375:229-240. doi:10.1007/s11104-013-1961-0.

Novais, R. F., and E. J. Kamprath. 1979. Parameters of phosphorus adsorption isotherms as criterion of recommendation of phosphorus fertilization. Revista Brasileira de Ciência do Solo 3:37-41.

Novais, R. F., and T. J. Smyth. 1999. Phosphorus in soil and plant in tropical conditions. Viçosa, Brazil: Federal Viçosa University Press.

Opik, H., and S. Rolfe. 2005. The physiology of flowering plants. Cambridge, United Kingdom: Cambridge University Press.

Rosolem, C. A., A. C. S. Almeida, and L. V. S. S. Sacramento. 1994. Soybean nutrition and root growth as affected by soil compaction. Bragantia 53:259-266. doi:10.1590/S0006-87051994000200016.

Siddiqi, M. Y., and A. D. M. Glass. 1981. Utilization index: A modified approach to the estimation and comparison of nutrient utilization efficiency in plants. Journal of Plant Nutrition 4:289-302. doi:10.1080/01904168109362919.

Silva, S. R., N. F. Barros, R. F. Novais, and P. R. G. Pereira. 2002. Eucalypt growth and nutritional efficiency of potassium under soil compaction. Revista Brasileira de Ciência do Solo 26:1001-1010. doi:10.1590/S010006832002000400018.

Silva, S. R., N. F. Barros, I. R. Silva, and N. B. Comerford. 2018. Diffusive fluxes of phosphorus, potassium and metallic microelements as affected by soil compaction. Communications in Soil Science and Plant Analysis 49:2369-2378. doi:10.1080/00103624.2018.1510947.

Silva, S. R., N. F. Barros, and J. E. B. Vilas Boas. 2006. Eucalyptus growth and nutrition as affected by Latosol compaction at different moistures. Revista Brasileira de Ciência do Solo 30:759-768. doi:10.1590/S010006832006000500001.

Skinner, A. K., I. D. Lunt, P. Spooner, and S. McIntyre. 2009. The effect of soil compaction on germination and early growth of Eucalyptus albens and an exotic annual grass. Austral Ecology 34:698-704. doi:10.1111/j.14429993.2009.01977.X.

Swiader, J. M., Y. Chyan, and F. G. Freiji. 1994. Genotypic differences in nitrate uptake and utilization efficiency in pumpkin hybrids. Journal of Plant Nutrition 7:1687-99. doi:10.1080/01904169409364840.

Tennant, D. A. 1975. A test of a modified line intersect method of estimating root length. Journal of Ecology 63:995 -1001 . doi:10.2307/2258617.

Tracy, S. R., C. R. Black, J. A. Roberts, and S. J. Mooney. 2011. Soil compaction: A review of past and present techniques for investigating effects on root growth. Journal of the Science of Food and Agriculture 91:1528-1537. doi:10.1002/jsfa.4424.

Tracy, S. R., C. R. Black, J. A. Roberts, C. Sturrock, S. Mairhofer, J. Craigon, and S. J. Mooney. 2012. Quantifying the impact of soil compaction on root system architecture in tomato (Solanum lycopersicum) by X-ray micro-computed tomography. Annals of Botany 110:511-519. doi:10.1093/aob/mcs031.

Valadão, F. C. A., O. L. S. Weber, D. D. Valadão Junior, A. Scapinelli, F. R. Deina, and A. Bianchini. 2015. Phosphorus fertilization and soil compaction: Soybean and maize root system and soil physical properties. Revista Brasileira de Ciência do Solo 39:243-255. doi:10.1590/01000683rbcs20150144. 